REFLEKSI HUKUM

Jurnal Imu Hukum
p-ISSN 2541-4984 | e-ISSN 2541-5417

Volume 5 Nomor 2, April 2021, Halaman 199-218

DOI: https://doi.org/10.24246/jrh.2021.v5.i2.p199-218

Open access at: http://ejournal.uksw.edu/refleksihukum

Penerbit: Fakultas Hukum Universitas Kristen Satya Wacana

\title{
PEMBUKTIAN TERBALIK PADA TINDAK PIDANA PENCUCIAN UANG
}

Sahuri Lasmadi

Fakultas Hukum Universitas Jambi|slasmadi@unja.ac.id

Elly Sudarti

Fakultas Hukum Universitas Jambi|elly_sudarti@unja.ac.id

\section{A R T I C L E I N F O \\ Article history: \\ Received \\ 11 Oktober 2020 \\ Revised \\ 18 November 2020 \\ Accepted \\ 15 April 2021}

\section{Kata-kata Kunci:}

Pembuktian

Terbalik; Tindak

Pidana; Pencucian

Uang.

\section{Keywords:}

Reversed Evidence, Money Laundering.

\section{Abstrak}

Penelitian ini dilatarbelakangi oleh sulitnya proses pembuktian pada tindak pidana pencucian uang yang kemudian digunakan mekanisme pembalikan beban pembuktian dalam pemeriksaan di pengadilan. Metode penelitian ini merupakan penelitian hukum normatif, menggunakan pendekatan undang-undang, konseptual, dan pendekatan kasus. Dari hasil henelitian dapat disimpukan: (1) Pembuktian terbalik diterapkan terhadap harta kekayaan terdakwa, baik untuk tindak pidana pencucian uang aktif (Pasal 3 dan Pasal 4) dan tindak pidana pencucian uang pasif (Pasal 5). Namun, konsep pembuktian terbalik tidak dijelaskan secara jelas dan tegas dalam Undang-Undang Pencegahan dan Pemberantasan Tindak Pidana Pencucian Uang, sehingga menimbulkan ketidakjelasan dalam pelaksanaannya. (2) Akibat hukum terhadap harta kekayaan terdakwa yaitu apabila terdakwa berhasil membuktikan bahwa harta kekayaan terdakwa bukan merupakan hasil tindak pidana, maka harta kekayaan tersebut tetap dalam penguasaan terdakwa dan ahli warisnya. Jika terdakwa tidak dapat membuktikan bahwa harta kekayaannya bukan hasil tindak pidana, maka harta kekayaan tersebut akan disita kemudian dirampas oleh negara setelah ada putusan pengadilan yang berkekuatan hukum tetap.
Abstract
This research is motivated by the difficulty of the proving process in the crime of money laundering in which mechanism to reverse the burden of proof is used during examination in court. This research is normative legal research, using a statutory, conceptual, and case approach. From the results of this research, it can be concluded: (1) Reverse evidence is applied to the assets of the defendant, both for active money laundering (Article 3 and Article 4) and passive money laundering (Article 5). However, the concept of reverse proof is not clearly and explicitly explained in the PP TPPU Law, confusing its implementation in court. (2) If the defendant succeeds in proving, the assets are still under the control of the accused and his heirs. On the other hand, if the defendant fails to prove, the defendant's assets will be confiscated by the State after a binding court decision is released. 


\section{PENDAHULUAN}

Pencucian uang merupakan jenis tindak pidana baru dalam referensi hukum pidana Internasional dan hukum pidana di Indonesia. Meskipun jenis tindak pidana baru proses penegakan hukum terhadap tindak pidana pencucian uang berkaitan secara langsung terhadap kebijakan ekonomi nasional dan dapat berdampak luas terhadap neraca finansial dan perbankan nasional di suatu negara.

Dengan hilangnya sekat-sekat batas negara karena perkembangan ekonomi dan teknologi informasi, seringkali hal ini digunakan sebagai celah bagi para pelaku kejahatan lintas negara (transnational crime) untuk mengembangkan bisnis kotor mereka di negara lain. Bahkan dalam beberapa kasus Organisasi kejahatan seperti mafia dan kartel narkoba menyimpan harta kekayaan mereka di negara lain, perbuatan demikian disebut sebagai kejahatan pencucian uang. Secara sepintas kejahatan pencucian uang tidak seperti kejahatan konvensional lainnya seperti perampokan, pencurian dan pembunuhan yang memiliki korban dan akibat nyata, bahkan menurut Billy Steel dalam Sutan Remy Sjahdeini mengemukakan bahwa "money laundering, it seems to be victimless crime". ${ }^{1}$ (Pencucian uang, kelihatannya merupakan kejahatan tanpa korban).

Selanjutnya Sutan Remy Sjahdeini mengemukakan bahwa hingga saat ini tidak terdapat definisi secara universal dan komprehensif terkait pengertian daripada pencucian uang atau money laundering. ${ }^{2}$ Karena tidak ada definisi internasional yang baku tentang pencucian uang maka setiap negara berhak untuk mendefinisikan pencucian uang yang sesuai dengan kondisi dan situasi di negara yang bersangkutan. Contohnya di Indonesia konsep tentang pencucian uang diatur dalam Undang-Undang Nomor 8 Tahun 2010 tentang Pencegahan Dan Pemberantasan Tindak Pidana Pencucian Uang (selanjutnya disebut UndangUndang PP TPPU) pada Pasal 1 angka 1 menyebutkan: "Pencucian Uang adalah segala perbuatan yang memenuhi unsur-unsur tindak pidana sesuai dengan ketentuan Undang-Undang ini". Perbuatan yang dilarang sebagai Tindak Pidana Pencuci Uang sebagaimana diatur pada Bab II meliputi Pasal 3, Pasal 4, Pasal 5, Pasal 6, Pasal 7, Pasal 8, Pasal 9 dan Pasal 10 Undang-Undang PP TPPU.

Lebih lanjut setelah melihat pendapat dari para ahli, Sutan Remy Sjahdeini merumuskan pengertian pencucian uang atau money laundering sebagai suatu proses dari rangkaian kegiatan yang dijalankan oleh seseorang atau organisasi terhadap uang haram yang berasal dari tindak pidana, yang kemudian disembunyikan atau disamarkan asal-usul uang haram tersebut melalui financial system, uang hasil kejahatan yang didapat secara melawan hukum, seolah-olah keluar dari financial system seolah-olah bukan uang yang bermasalah maka akan tercatat sebagai uang yang halal. ${ }^{3}$

Sutan Remy Sjahdeini, Seluk Beluk Tindak Pidana Pencucian Uang dan Pembiayaan Terorisme (Ed. 2, Pustaka Utama Grafiti Jakarta 2007) 16.

2 Halif, 'Penyelesaian Tindak Pidana Pencucian Uang Yang Tidak Dibuktikan Terlebih Dahulu Tindak Pidana Asalnya' (2016) 14 (2) Jurnal Era Hukum 238, 262.

$3 \quad$ Sjahdeini (n 1) 5. 
Pencucian uang secara umum telah digolongkan sebagai suatu tindak pidana dan tergolong kejahatan kerah putih, ${ }^{4}$ dan dianggap sebagai kejahatan luar biasa (extraordinary crime) atau bahkan kejahatan serius (serious crime) karena memiliki modus operandi yang berbeda dan lebih berbahaya dari kejahatan konvensional yang dikenal dalam hukum pidana di Indonesia. ${ }^{5}$ Tindak pidana pencucian uang membawa dampak yang sangat merugikan terhadap ekonomi, keuangan, sosial, dan keamanan, bahkan karena ruang lingkupnya sudah bersifat cross border, maka pencucian uang dianggap sebagai transnational crime yang sudah mejadi fenomena dunia dan tantangan internasional.

Pemerintah Indonesia terkait dengan politik hukum tindak pidana pencucian uang telah membentuk berbagai peraturan perundang-undangan terkait dalam rangka penanggulangan tindak pidana pencucian uang, terakhir adalah UndangUndang PP TPPU.

Salah satu masalah kompleks pengusutan tindak pidana pencucian uang yakni dalam proses pembuktian tindak pidana pencucian uang tersebut tidak mudah serta dalam praktik tidak efektif, karena berdasarkan pengalaman negara maju, untuk pembuktian tindak pidana ini sangat sulit jika tempat kejadian perkara berada di luar negeri atau wewenang mengadili di luar wilayah negara yang bersangkutan dan nilai kejahatan pencucian uang tersebut dilihat kerugiannya sangat berarti, apalagi antar negara tersebut tidak ada kerjasama internasional terkait kejahatan tersebut. 6 Tentunya hal demikian akan mempersulit instansi penegak hukum dalam upaya pemberantasan pencucian uang di berbagai negara di dunia termasuk di Indonesia.

Proses pembuktian dalam Tindak Pidana Pencucian Uang memiliki perbedaan dari pemeriksaan kasus pidana pada umumnya, karena tindak pidana pencucian uang merupakan kejahatan yang luar biasa (extraordinary crime), jadi proses penanggulangannya harus menggunakan upaya yang luar biasa juga (extraordinary Enforcement). Salah satu bentuk upaya luar biasa tersebut adalah dalam konteks pembuktian perkara pencucian uang di pengadilan yang menggunakan mekanisme pembalikan beban pembuktian atau pembuktian terbalik yang terbatas dan berimbang. ${ }^{7}$

Adapun alasan diterapkannya pembuktian terbalik untuk tindak pidana pencucian uang karena pencucian uang dianggap sebagai tindak pidana yang dilakukan dengan cara yang rumit serta melibatkan pelaku yang memiliki jaringan kejahatan (crime network) yang terorganisir sehingga dalam proses pembuktian di pengadilan kadangkala penuntut umum kesulitan dalam membuktikan kasus pencucian uang di pengadilan, ditambah pula semakin mutakhirnya teknologi informasi di bidang keuangan dan perbankan membuat sulit menjerat pelaku tindak pidana ini.

Proses pembuktian terbalik dalam pemeriksaan perkara tindak pidana pencucian uang juga bukan tanpa polemik, banyak sekali ahli hukum yang

$4 \quad$ Munir Fuady, Bisnis Kotor: Anatomi Kejahatan Kerah Putih (PT Citra Aditya Bakti Bandung 2011) 11 .

5 Roberts Kennedy, Pengembalian Aset Hasil Kejahatan (Dalam Perspektif Rezim Anti Pencucian Uang) (Rajawali Pers Depok 2017) 2.

Ibid., 7.

Kukun Abdul Syakur Munawar, 'Pembuktian Terbalik Sebagai Kebijakan Kriminal Dalam Penanganan Tindak Pidana Korupsi‘ (2017) 5 (2) Jurnal Ilmiah Galuh Justisi 224, 245. 
menentang diterapkannya pembuktian terbalik, alasannya pembuktian terbalik mengingkari asas hukum pidana Indonesia mulai dari asas praduga tak bersalah Pasal 8 ayat (1) Undang-Undang Nomor 48 Tahun 2009 tentang Kekuasaan Kehakiman, asas mempersalahkan diri sendiri pada Pasal 66 Kitap Undang-Undang Hukum Acara Pidana (selanjutnya disebut KUHAP) yang menyatakan "tersangka atau terdakwa tidak dibebani kewajiban pembuktian", berbagai konvensi internasional tentang HAM yang telah diratifikasi oleh Indonesia, ${ }^{8}$ sehingga dapat dilihat bahwa karena proses pembuktian terbalik terjadi pengurangan terhadap perlindungan hak terdakwa di muka pengadilan dan juga konsep ini berkonflik dengan peraturan perundang-undangan yang lain.

Berkaca dari kasus Muhammad Nazaruddin yang menjadi terdakwa kasus korupsi dan pencucian uang dapat dilihat bagaimana rumitnya proses pembuktian terbalik dalam kasus pencucian uang. Bahkan jaksa dari KPK dalam beberapa kali kesempatan kesulitan dalam merampas harta kekayaan terdakwa yang merupakan hasil kejahatan. Terdakwa Muhammad Nazaruddin berkilah bahwa aset yang akan disita bukan miliknya melainkan milik dari orang lain. Beda pula cara untuk menyamarkan aset hasil kejahatan yang dilakukan oleh Irjen Djoko Susilo mantan Kakorlantas Polri yang terjerat kasus korupsi Simulator SIM tersebut menyamarkan aset hasil korupsi dengan nama istri siri dan orang dekat pelaku.

Pembuktian terbalik banyak dikritisi oleh para ahli hukum pidana, dan menjadi polemik dalam penerapannya, karenanya ahli hukum pidana bernama Oliver Stolpe memberikan alternatif Teori Pembalikan Beban Pembuktian Keseimbangan Kemungkinan, konsep teori pembuktian ini adanya teori probabilitas yang diturunkan dalam hal kepemilikan harta kekayaan hasil dari tindak pidana akan tetapi tetap mempertahankan teori probabilitas yang sangat tinggi dalam hal perampasan kemerdekaan seseorang. ${ }^{9}$

Apabila dikaitkan dengan pembuktian terbalik pada tindak pidana pencucian uang dalam perspektif sistem peradilan pidana, maka dalam konteks hukum pidana di Indonesia persoalannya adalah, pertama, bagaimana pengaturan pembuktian terbalik pada perkara tindak pidana pencucian uang di Indonesia. Kedua, apa akibat hukum terhadap harta kekayaan terdakwa dalam proses pembuktian terbalik perkara tindak pidana pencucian uang?

Kajian tentang pembuktian terbalik pada tindak pidana pencucian uang dalam perspektif sistem peradilan pidana dalam artikel ini dilakukan dengan menggunakan metode penelitian yuridis normatif atau doktrinal. Pendekatan penelaahan yang digunakan adalah perundang-undangan, konseptual, dan kasus. Bahan hukum yang digunakan meliputi bahan hukum primer, berupa peraturan perundang-undangan, dan dokumen hukum lainnya terkait dengan pembuktian terbalik pada tindak pidana pencucian uang; bahan hukum sekunder berupa referensi tentang pembuktian terbalik pada tindak pidana pencucian uang dalam perspektif sistem peradilan pidana; dan bahan hukum tersier. Analisis dilakukan

\footnotetext{
8 Lestari Victoria Sinaga, 'Alvi Syahrin, M. Hamdan, Dedi Harianto, Penerapan Pembuktian Terbalik Dalam Perkara Gratifikasi' (2016) 4 (2) USU Law Journal 90,97.

9 Muhammad Yusuf, 'Merampas Aset Koruptor Solusi Pemberantasan Korupsi di Indonesia' Kompas $\quad$ Jakarta, 6 April $\quad$ 2013) https://edukasi.kompas.com/read/2013/04/16/13412749/rampas.aset.koruptor.solusi.pemb erantasan.korupsi. > di akses tanggal 6 Juni 2020.
} 
melalui tahapan interpretasi bahan hukum, penilaian bahan hukum, serta evaluasi bahan peraturan perundang-undangan yang berhubungan dengan masalah yang dibahas.

\section{PEMBAHASAN}

\section{Pengaturan Pembuktian Terbalik Dalam Perkara Tindak Pidana Pencucian Uang di Indonesia}

Konstitusi Indonesia menyatakan bahwa Indonesia adalah negara hukum (Recht staats) bukan negara berdasarkan atas kekuasaan (Macht staats). ${ }^{10}$ Khusus dalam hukum pidana untuk membuktikan bahwa seseorang bersalah atau tidak bersalah melakukan perbuatan pidana adalah melalui mekanisme pembuktian di pengadilan. Negara Indonesia merupakan bekas koloni Hindia Belanda jadi Indonesia juga menganut sistem beban pembuktian yang sama dengan Belanda (Eropa Kontinental) yang memberikan beban pembuktian pada penuntut umum. Sebetulnya secara universal beban pembuktian pada penuntut umum juga digunakan oleh beberapa negara yang menganut sistem hukum Anglo-Saxon.

Seiring berjalannya waktu beban pembuktian pada penuntut umum dianggap tidak efektif dalam memberantas tindak pidana luar biasa (Extra ordinary crime) seperti korupsi dan pencucian uang. Oleh karena itu muncul ide untuk mengadopsi sistem "Pembalikan Beban Pembuktian" proses pembuktian yang sudah lebih dahulu ada dalam sistem hukum Anglo-Saxon. Setelah diskusi dan perdebatan yang panjang antara pemerintah dengan parlemen akhirnya dihasilkan jalan tengah yaitu dengan menerapkan pembalikan beban pembuktian yang terbatas dan berimbang. (Menurut Undang-Undang PP TPPU, pembuktian terbalik menjadi kewajiban terdakwa, terdakwa diwajibkan membuktikan harta kekayaannya bukan hasil tindak pidana, namun jaksa penuntut umum tetap diberikan beban untuk membuktikan unsur kesalahan terdakwa. Pada Pasal 77 disebutkan, untuk kepentingan pemeriksaan di sidang pengadilan, terdakwa wajib membuktikan bahwa harta kekayaannya bukan merupakan hasil tindak pidana sebagaimana diatur pada Pasal 77, lebih lanjut dan pada Pasal 78 Undang-Undang PP TPPU bahwa terdakwa membuktikan bahwa harta kekayaan yang terkait dengan perkara bukan berasal atau terkait dengan tindak pidana sebagaimana dimaksud dalam Pasal 2 ayat (1) dengan cara mengajukan alat bukti yang cukup.

Dalam hukum positif Indonesia pembalikan beban pembuktian atau lebih dikenal dengan istilah pembuktian terbalik diadopsi dalam dua peraturan perundang-undangan yaitu Undang-Undang Nomor 31 Tahun 1999 tentang Pemberantasan Tindak Pidana Korupsi sebagaimana telah diubah dengan UndangUndang Nomor 20 Tahun 2001 tentang Perubahan atas Undang-Undang Nomor 31 Tahun 1999 tentang Pemberantasan Tindak Pidana Korupsi (Selanjutnya disebut UU Pemberantasan Tipikor) dan Undang-Undang PP TPPU. Sesuai dengan ide awal pemerintah maka pembuktian terbalik yang terbatas dan berimbang dalam UU Pemberantasan Tipikor hanya dapat diterapkan dalam 2 (dua) objek pembuktian yaitu:

10 Zahermann Armandz Muabezi, 'Negara Berdasarkan Hukum (Rechtsstaats) Bukan Kekuasaan (Machtsstaat)' (2017) 6 (3) Jurnal Hukum Dan Peradilan 421, 446. 
1. Pada "korupsi suap menerima gratifikasi" yang nilainya Rp. 10.000.000.00.(Sepuluh juta rupiah) atau lebih (Pasal 12B ayat (1) huruf a Jo Pasal 37); dan

2. Pada "harta benda terdakwa" yang terbagi dalam 2 (dua) jenis yakni:

a. Harta benda yang didakwakan dan yang ada hubungannya dengan pembuktian tindak pidana korupsi dalam perkara pokok (Pasal 37A).

b. Harta benda terdakwa yang belum didakwakan (Pasal 38B Jo Pasal 37). ${ }^{11}$

Sedangkan dalam Undang-Undang PP TPPU pembuktian terbalik diterapkan dalam 2 (dua) jenis tindak pidana pencucian uang:

1. Tindak pidana pencucian uang aktif (Pasal 3 dan Pasal 4).

Tindak pidana pencucian uang sebagaimana dimaksud dalam Pasal 3, mempergunakan frasa "menempatkan, mentransfer, mengalihkan, membelanjakan, membayarkan, menghibahkan, menitipkan, membawa keluar negeri, mengubah bentuk, menukarkan dengan mata uang, atau surat berharga atau perbuatan lain yang merupakan kalimat aktif dalam perumusan Pasal 3, maka dapat diketahui bahwa tindak pencucian uang sebagaimana dimaksud dalam Pasal 3 dalam kepustakaan tindak pidana pencucian uang termasuk atau disebut tindak pidana pencucian uang aktif. 12

Tindak pidana pencucian uang sebagaimana dimaksud dalam Pasal 4, mempergunakan frasa "menyembunyikan" dan "menyamarkan" yang merupakan kalimat aktif dalam perumusan Pasal 4, maka dapat diketahui tindak pidana pencucian uang sebagaimana dimaksud dalam Pasal 4, dalam kepustakaan tindak pidana pencucian uang adalah termasuk atau disebut tindak pidana pencucian uang aktif. ${ }^{13}$

2. Tindak pidana pencucian uang pasif (Pasal 5).

Tindak pidana pencucian uang sebagaimana dimaksud dalam Pasal 5, mempergunakan frasa "menerima" dan "menguasai" yang merupakan kalimat pasif dalam perumusan Pasal 5, dalam kepustakaan tindak pidana pencucian uang adalah termasuk atau disebut tindak pidana pencucian uang pasif. ${ }^{14}$

Undang-Undang PP TPPU memang memberikan kewajiban beban pembuktian kepada terdakwa, namun perumus Undang-Undang tidak memberikan penjelasan yang komprehensif tentang bagaimana pengaturan pembuktian terbalik dalam Undang-Undang PP TPPU tersebut. Sayangnya berdasarkan Pasal 77 dan 78 undang-undang tersebut tidak diatur perihal prosedur beracaranya atau setidaktidaknya mengatur konsekuensi dari pembuktian terbalik tersebut. Semestinya undang-undang tegas mengatur konsekuensi dari pembuktian terbalik yang dilakukan terdakwa.

Pada Undang-Undang PP TPPU, Pasal 77 adalah pasal pembuka yang membahas ketentuan pembuktian terbalik, Pasal 77 menyatakan "Untuk kepentingan pemeriksaan sidang pengadilan, terdakwa wajib membuktikan bahwa

11 Nurasia Tanjung, 'Pembuktian Terbalik Atas Harta Kekayaan Seseorang Tersangka Korupsi' (2016) 5 (2) Lex Crimen 109, 117.

12 R. Wiyono, Pembahasan Undang-Undang Pencegahan Dan Pemberantasan Tindak Pidana Pencucian uang (Sinar Grafika Jakarta 2014) 54.

$13 \quad$ Ibid., 68

$14 \quad$ Ibid. 
harta kekayaannya bukan merupakan hasil tindak pidana". kalimat dalam Pasal ini sama dengan kalimat pada Undang-Undang sebelumnya dan dari ketentuan ini pula hakim dapat memerintahkan terdakwa atau penasihat hukum untuk membuktikan harta kekayaan yang dimiliki oleh terdakwa bukan terkait tindak pidana yang didakwakan oleh penuntut umum. Pasal ini berhubungan dengan Pasal 78 UndangUndang PP TPPU yang berisi tentang bagaimana cara terdakwa atau penasihat hukumnya membuktikan asal-usul harta kekayaan milik terdakwa. Pasal 78 terbagi menjadi dua ayat yang menyatakan:

1) Dalam pemeriksaan di sidang pengadilan sebagaimana dimaksud dalam Pasal 77, hakim memerintahkan terdakwa agar membuktikan bahwa Harta Kekayaan yang terkait dengan perkara bukan berasal atau terkait dengan tindak pidana sebagaimana dimaksud dalam Pasal 2 ayat (1).

2) Terdakwa membuktikan bahwa Harta Kekayaan yang terkait dengan perkara bukan berasal atau terkait dengan tindak pidana sebagaimana dimaksud dalam Pasal 2 ayat (1) dengan cara mengajukan alat bukti yang cukup.

Selanjutnya Pasal 78 ayat (2) Undang-Undang PP TPPU yang menyatakan bahwa "terdakwa membuktikan Harta Kekayaan yang terkait dengan perkara bukan berasal atau terkait dengan tindak pidana sebagaimana Pasal 2 ayat (1) dengan cara mengajukan alat bukti yang cukup". Pasal ini berhubungan dengan ketentuan alat bukti yang tercantum Pasal 73 Undang-Undang PP TPPU yang menjelaskan secara eskplisit bentuk-bentuk alat bukti yang sah dalam pembuktian tindak pidana pencucian uang, dan sesuai dengan konsep awal pembuktian terbalik maka terdakwa atau penasihat hukum dalam membuktikan secara terbalik bahwa harta kekayaannya tidak terkait tindak pidana juga menggunakan alat bukti sesuai dalam Pasal 73 Undang-Undang PP TPPU.

Mengenai penjelasan kalimat "dengan cara mengajukan alat bukti yang cukup" dalam Pasal 78 ayat (2). Memang dalam Undang-Undang PP TPPU tidak dijelaskan mengenai batas minimal alat bukti, karena tidak ada batasan ketentuan alat bukti dalam perkara pencucian uang, maka secara otomatis kembali lagi pada Pasal 183 KUHAP, yang merupakan pedoman dalam hukum acara pidana di Indonesia. Dengan demikian jika terdakwa atau penasihat hukum tidak dapat menghadirkan sekurang-kurangnya 2 (dua) alat bukti yang mampu meyakinkan hakim bahwa harta kekayaannya diperoleh secara sah, maka dengan sendirinya dakwaan Tindak Pidana Pencucian Uang yang diajukan Jaksa penuntut umum terbukti. ${ }^{15}$

Pembuktian terbalik terhadap asal usul aset atau harta kekayaan yang tidak wajar yang dimiliki oleh terdakwa dapat dilakukan seminimal mungkin dalam kaitannya bersinggungan hak asasi terdakwa apabila pihak jaksa penuntut umum terlebih dahulu membuktikan harta kekayaan milik terdakwa kemudian diikuti oleh terdakwa untuk membuktikan harta kekayaan miliknya. ${ }^{16}$ Pembuktian terhadap harta kekayaan milik terdakwa merupakan suatu kewajiban yang tercantum dalam undang-undang, bukan dalam bentuk hak yang dapat digunakan atau tidak dapat digunakan.

15 Yudi Kristiana, Pemberantasan Tindak Pidana Pencucian Uang Perspektif Hukum Progresif (Thafa media Yogyakarta 2015) 265.

16 Silva Da Rosa, 'Perlindungan Terhadap Pelaku Tindak Pidana Korupsi Dalam Pelaksanaan Perampasan Aset Secara Tidak Wajar' (2018) 2 (2) Jurnal Bina Mulia Hukum 206. 
Pembuktian terbalik yang menjadi kewajiban terdakwa tindak pidana pencucian uang untuk membuktikan bahwa asal usul harta kekayaan yang dimiliki bukan berasal dari tindak pidana sebagaimana dimaksud dalam Pasal 2 ayat (1). Dasar hukum pembuktian terbalik ini diatur pada Pasal 77 dan 78 Undang-Undang PP TPPU. Pada Pasal 77 disebutkan bahwa untuk kepentingan pemeriksaan di sidang pengadilan, terdakwa wajib membuktikan bahwa harta kekayaannya bukan merupakan hasil tindak pidana. Sistem pembuktian terbalik pada tindak pidana pencucian uang pada Pasal 77 dan 78 adalah untuk kepentingan pemeriksaan di sidang pengadilan. Oleh sebab itu pembuktian terbalik hanya dapat diterapkan pada waktu dilakukan pemeriksaan di sidang pengadilan.

Konsep pembuktian terbalik pada tindak pidana pencucian uang adalah konsep pembuktian terbalik terbatas dan berimbang. Maksud terbatas adalah pembuktian terbalik dibatasi pada tindak pidana tertentu, sedangkan maksud dari berimbang adalah penuntut umum tetap berkewajiban untuk membuktikan dakwaannya. ${ }^{17}$

Ada dua kemungkinan, apakah terdakwa tidak dapat membuktikan bahwa harta kekayaan yang dimilikinya bukan berasal dari hasil tindak pidana. Jika terdakwa tidak dapat membuktikan bahwa harta kekayaannya bukan merupakan hasil tindak pidana, maka dapat menjadi petunjuk bagi hakim bahwa harta kekayaan terdakwa berasal atau hasil dari tindak pidana. Sebaliknya, jika terdakwa dapat membuktikan bahwa harta kekayaan yang dimilikinya bukan berasal dari hasil tindak pidana, maka jaksa penuntut umum tidak kehilangan hak untuk membuktikan, bahwa harta kekayaan terdakwa berasal dari tindak pidana. Artinya jaksa penuntut umum yang mendakwa tetap harus membekali diri dengan sejumlah alat bukti untuk membuktikan dakwaannya. Dalam kondisi dimana terdakwa dapat membuktikan bahwa dia tidak bersalah, sedangkan jaksa penuntut umum membuktikan bahwa terdakwa bersalah, maka penilaian terhadap alat bukti-bukti yang ada dalam persidangan ada pada hakim. Jadi pembuktian terbalik dalam praktik harus diterapkan dalam proses pembuktian di Pengadilan Tindak Pidana Korupsi dan Tindak Pidana Pencucian Uang.

Dalam hukum pidana dikenal asas actori incumbit onus probandi artinya siapa yang menuntut dialah yang wajib membuktikan. Dalam konteks hukum pidana yang melakukan penuntutan adalah jaksa penuntut umum sehingga jaksa penuntut umumlah yang wajib membuktikan kesalahan terdakwa. ${ }^{18}$ Teknis pembuktian dalam persidangan tindak pidana pencucian uang sebenarnya penuntut umum membuktikan terlebih dahulu dakwaan tindak pidana pencucian uang kemudian setelah itu baru giliran dari terdakwa untuk membuktikan bahwa harta kekayaan terdakwa tidak terkait atau berasal dari tindak pidana sesuai yang didakwakan oleh penuntut umum. Dalam praktik surat dakwaan biasanya disusun dalam bentuk gabungan antara tindak pidana asal dan tindak pidana pencucian uang. Alasan mengapa hal ini dilakukan karena urutan peristiwa (sequence) harus dijelaskan dari mulai tindak pidana asal yang kemudian bermuara ke tindak pidana pencucian uang.

17 Lilik Mulyadi, 'Asas Pembalikan Beban Pembuktian Terhadap Tindak Pidana Korupsi Dalam Sistem Hukum Pidana Indonesia Dihubungkan Dengan Konvensi Perserikatan Bangsa-Bangsa Anti Korupsi 2003' (2015) 4 (1) Jurnal Hukum dan Peradilan 101. 
Untuk mendorong proses pembuktian terbalik yang adil dan tepat sasaran baik itu penyidik ataupun penuntut umum akan berkoordinasi dengan Pusat Pelaporan dan Analisis Transaksi Keuangan (PPATK) untuk melakukan pelacakan secara menyeluruh terhadap harta kekayaan yang dimiliki oleh terdakwa. Proses ini dilakukan untuk mencegah adanya "blind confiscation" perampasan aset secara buta terhadap keseluruhan harta kekayaan milik terdakwa. Tidak dapat dipungkiri juga bahwa tidak semua harta kekayaan milik terdakwa berasal atau terkait dengan tindak pidana, sehingga dalam proses penegakan hukum yang adil dan tepat penyidik dan instansi terkait harus secara cermat dan teliti untuk memisahkan harta kekayaan hasil tindak pidana dan harta kekayaan yang tidak terkait tindak pidana.

Ketentuan dalam Pasal 77 Undang-Undang PP TPPU secara eksplisit membatasi penuntut umum agar selektif menentukan harta kekayaan yang wajib atau tidak wajib dibuktikan oleh terdakwa19. Jadi dapat ditarik kesimpulan bahwa hanya harta kekayaan yang tercantum dalam surat dakwaan penuntut umum saja yang wajib dibuktikan oleh terdakwa dan bukan harta kekayaan yang tidak tercantum dalam surat dakwaan penuntut umum dan bukan seluruh harta kekayaan yang dimiliki oleh terdakwa. Sungguh ironi bahwa hukum positif Indonesia tentang pencucian uang tidak mengatur regulasi tentang bagaimana mekanisme perampasan terhadap harta kekayaan yang tidak ikut dirampas dalam proses pidana, berbanding terbalik dengan UU Pemberantasan Tipikor yang memberikan alternatif kepada penuntut umum untuk mengajukan gugatan secara perdata terhadap ahli waris terdakwa atas harta kekayaan yang diduga keras (probable cause) berasal atau terkait dengan tindak pidana korupsi.

Pembuktian terbalik yang terbatas dan berimbang tidak terlalu memberikan keringanan bagi jaksa penuntut umum. Alasannya adalah jaksa penuntut umum tetap mempersiapkan alat-alat bukti untuk memperkuat dakwaan tindak pidana pencucian uang dan penuntut umum juga berkewajiban membuktikan harta kekayaan terdakwa merupakan hasil dari tindak pidana. Bahkan konsep pembuktian terbalik dapat digunakan sebagai celah oleh terdakwa atau penasihat hukum untuk dapat menyerang bukti-bukti yang diajukan oleh penuntut umum. Jadi tanpa persiapan alat bukti yang matang dalam proses penyidikan maka dalam proses pembuktian terbalik dapat menjadi bumerang kepada pihak jaksa penuntut umum sendiri karena terdakwa atau penasihat hukumnya dapat menyertakan bukti-bukti baru yang belum diverifikasikan sebelumnya dengan pihak jaksa penuntut umum. oleh karena itu perlu juga ditingkatkan profesionalisme dan kompetensi penegak hukum baik itu Polri, Kejaksaan, BNN, KPK, Dirjen Bea Cukai, Dirjen Pajak agar konsep pembuktian terbalik dalam Undang-Undang ini dapat berjalan secara efektif dan efisien.

Konsep pembuktian terbalik pada Undang-Undang PP TPPU sebenarnya memiliki tujuan untuk merampas harta kekayaan terdakwa dan pengembalian kerugian negara (Asset Recovery) melalui proses pemidanaan (Conviction based forfeiture) yang dilakukan dengan penjatuhan pidana denda, perampasan harta kekayaan terdakwa, pembayaran biaya perkara dan pembayaran uang pengganti

19 Romli Atmasasmita, Sistem Peradilan Pidana Kontemporer (Kencana Prenada Media Group Jakarta 2011) 19. 
(diterapkan pada Tipikor saja). Setiap sanksi tersebut dijatuhkan bersama-sama dengan pidana penjara dan proses eksekusi terhadap putusan tersebut merupakan kewajiban dari penuntut umum. Pembuktian terbalik dalam Undang-Undang PP TPPU memang ditujukan terhadap harta kekayaan terdakwa yang diduga berasal dari tindak pidana namun tidak dapat dipungkiri bahwa proses pembuktian ini juga terkait dan mempengaruhi pembuktian atas dakwaan tindak pidana pencucian uang terhadap terdakwa itu sendiri. Sehingga apabila tidak dilakukan dengan cermat dan hati-hati proses pembuktian terbalik dapat melanggar hak-hak dasar dari terdakwa ${ }^{20}$. Asas pembuktian terbalik juga bertentangan dengan beberapa asas hukum pidana yaitu asas praduga tak bersalah (presentation of innocence) dan non self incrimination. ${ }^{21}$

Pembuktian terbalik yang terbatas dan berimbang dipilih oleh Indonesia daripada pembuktian terbalik murni atau absolut untuk meminimalisir pelanggaran hak-hak terdakwa. Namun jika dianalisis dengan seksama maka baik itu pembuktian terbalik yang terbatas dan berimbang dan pembuktian terbalik murni atau absolut sama-sama melanggar hak-hak terdakwa, ${ }^{22}$ bedanya bila pembuktian terbalik murni atau absolut secara langsung mengubah konsep dasar hukum pidana di Indonesia sekaligus bertentangan dengan asas hukum dan konstitusi Indonesia terlebih lagi Indonesia juga telah mengadopsi Undang-Undang Nomor 39 Tahun 1999 tentang Hak Asasi Manusia serta berbagai konvensi internasional tentang HAM yang telah diratifikasi oleh Indonesia, sehingga jelas apabila pembuktian terbalik absolut diterapkan akan bertentangan dengan Undang-Undang yang lain.

Pembuktian terbalik absolut jika dilihat dari sudut pandang HAM, jelas melanggar HAM. Namun dalam konteks penegakan hukum untuk tindak pidana luar biasa seperti tindak pidana pencucian uang maka proses pembuktian terbalik absolut harus diatur secara komprehensif dalam Undang-Undang PP TPPU agar dapat dilakukan pada proses penyidikan oleh penyidik terhadap harta kekayaan tersangka. Oleh sebab itu penyidik harus dapat mengumpul alat bukti, sekurangkurangnya dua alat bukti yang sah terjadinya tindak pidana pencucian uang. Berdasarkan Pasal 74 Undang-Undang PP TPPU bahwa penyidik tindak pidana asal baru dapat melakukan penyidikan tindak pidana pencucian uang jika telah ditemukan sekurang-kurangnya dua alat bukti yang sah.

Konsep pembuktian terbalik murni ini dapat dicoba untuk diterapkan terhadap tindak pidana pencucian uang atau tindak pidana khusus lainnya, meskipun harus dibarengi dengan regulasi hukum yang ketat dan peningkatan kualitas dan profesionalisme SDM penegak hukum di Indonesia khusus untuk tindak pidana pencucian uang baik itu dari institusi POLRI, Kejaksaan, KPK, Bea Cukai, BNN dan Dirjen Pajak. Melalui regulasi hukum yang ketat akan mengawasi segala perilaku penegak hukum agar tidak menyalahgunakan kekuasaan (Abuse of power) untuk memeras ataupun memperalat keadaan tersangka untuk kepentingan pribadi dan

20 Alfitra, Hukum Pembuktian Dalam Beracara Pidana, Perdata, dan Korupsi di Indonesia (Raih Asa Sukses Jakarta 2012) 159.

$21 \quad$ Adrian Sutedi, Tindak Pidana Pencucian Uang (PT Citra Aditya Bakti Jakarta 2008) 291.

22 Afrianto Sagita, 'Pembaharuan Kebijakan Hukum Pidana Terkait Beban Pembuktian Pada Tindak Pidana Korupsi Dalam Rangka Pengembalian Kerugian Keuangan Negara' (2018) 17 (2) Jurnal Hukum Respublica 309. 
golongan. Perlu digarisbawahi juga satu hal penting apabila pembuktian terbalik murni diterapkan dalam tindak pidana pencucian uang yaitu diperlukannya kerjasama yang solid antar institusi penegak hukum dengan PPATK. Kerjasama ini diperlukan agar proses pembuktian terbalik murni nantinya dapat terlaksana secara efektif dan efisien.

Selain pembuktian terbalik murni, Indonesia juga bisa mengadopsi teori pembalikan beban pembuktian keseimbangan kemungkinan (Balanced probability principles). ${ }^{23}$ Teori ini secara teoretis tidak bersinggungan dengan hak-hak terdakwa karena penuntut umum akan membuktikan secara negatif kesalahan pelaku (Negatief wettelijk bewijstheorie), kemudian di saat yang bersamaan terdakwa membuktikan kepemilikan harta kekayaan menggunakan teori probabilitas berimbang (Balanced probabilities). ${ }^{24}$

Teori Balanced probabilities dianggap memberikan jaminan perlindungan hak terdakwa untuk tidak dianggap bersalah (Presumption of innocence) sebelum adanya putusan yang berkekuatan hukum tetap, namun teori ini tidak memberikan jaminan perlindungan terhadap harta kekayaan terdakwa yang diduga berasal dari tindak pidana kecuali terdakwa bisa membuktikan sebaliknya. ${ }^{25}$ Dalam praktik teori Balanced probabilities telah diterapkan di banyak negara dan terbukti efektif memberantas berbagai kejahatan terorganisir yang ada mulai dari kartel narkoba sampai pejabat pemerintahan. Khususnya harus ada perubahan kompleks dalam konsep pemidanaan dalam hukum pidana khusus di Indonesia baik itu dalam Undang-Undang Tipikor, pencucian uang, narkotika dan lain-lain. Jika dahulu berfokus pada pemidanaan bagi pelaku, saat ini pemidanaan berorientasi kepada perampasan harta kekayaan hasil tindak pidana.

Teori keseimbangan kemungkinan diterapkan dengan tegas serta tetap memperhatikan keseimbangan (Balanced principle) dan tidak bersifat merugikan kepentingan atau hak terdakwa. ${ }^{26}$ Jika dianalisis secara seksama teori Balanced Probabilities ditujukan untuk perampasan aset atau harta kekayaan milik terdakwa dan juga untuk menghukum terdakwa atas kejahatan yang dilakukan. Diharapkan dengan memutus pendanaan kegiatan kejahatan dan meringkus para pelakunya maka dengan sendirinya akan mengguncang keadaan finansial organisasi kejahatan tersebut. Tanpa adanya harta kekayaan otomatis kegiatan kejahatan tersebut tidak dapat beroperasi dan bermuara dengan tidak dilakukannya tindak pidana tersebut karena ketiadaan modal untuk melakukan operasional kejahatan tersebut.

\section{Akibat Hukum Terhadap Harta Kekayaan Dalam Proses Pembuktian Terbalik Perkara Tindak Pidana Pencucian Uang}

Uang memiliki peranan penting dalam hidup manusia, tidak jarang demi mendapatkan uang manusia melakukan segala cara baik itu yang diperbolehkan ataupun yang melanggar hukum. Dalam organisasi kejahatan (crime organization)

\footnotetext{
23 Muhammad Yusuf, Mengenal, Mencegah, Memberantas Tindak Pidana Pencucian Uang (Jakarta: Pustaka Juanda Tigalima 2014) 66.

24 Afrianto Sagita, 'Pembalikan Beban Pembuktian Sebagai Kebijakan Hukum Pidana Dalam Undang-Undang Tindak Pidana Korupsi. Jurnal Hukum Respublica' (2017) 17 (1) Jurnal Hukum Respublica 22.

25 Yusuf (n 23)

$26 \quad$ Yusuf (n 23) 77.
} 
uang merupakan komponen penting yang menggerakkan roda kejahatan dan tidak jarang harta kekayaan digunakan untuk ekspansi bisnis kejahatan di negara tetangga. Sampai saat ini penegakan hukum di negara berkembang seperti Indonesia masih berfokus pada pemidanaan pelaku kejahatan tanpa memperdulikan harta kekayaan yang dimiliki oleh terdakwa. Namun seiring berjalannya waktu ditambah adanya dorongan dari komunitas internasional maka telah ada perubahan untuk mulai menelusuri harta kekayaan terdakwa yang berasal dari kejahatan. Dalam organisasi kejahatan harta kekayaan memiliki tempat yang sangat tinggi sehingga tidak jarang anggota organisasi kejahatan rela untuk dipenjara selama waktu tertentu asalkan harta kekayaan tidak tersentuh oleh otoritas penegak hukum.

Undang-Undang PP TPPU Pasal 1 butir (13) mengartikan "Harta kekayaan adalah semua benda bergerak atau benda tidak bergerak, baik yang berwujud maupun tidak berwujud, yang diperoleh baik secara langsung maupun tidak langsung". Frasa Harta kekayaan selalu tercantum dalam delik pencucian uang baik itu pencucian uang aktif dan pencucian uang pasif, bahkan unsur mengetahui dan patut diduga (knowledge or reason to know) bahwa harta kekayaan hasil dari tindak pidana merupakan unsur krusial dalam delik pencucian uang. Bahkan bisa dibilang tanpa adanya harta kekayaan hasil tindak pidana maka tindak pidana pencucian uang dianggap tidak pernah terjadi. Saat ini di dunia telah terjadi pergeseran paradigma penegakan hukum tindak pidana pencucian uang dari "follow the suspect" menuju orientasi pada aset atau harta kekayaan "follow the money" pengembalian aset tindak pidana untuk kepentingan negara ataupun pihak yang dirugikan merupakan tujuan utama dari konsep "follow the money". ${ }^{27}$ Di samping itu konsep "follow the money" juga memiliki pendekatan preventif yaitu pelaporan transaksi mencurigakan atau pengawasan terhadap institusi perbankan dan pendekatan represif yaitu pemidanaan pelaku dan perampasan harta kekayaan hasil kejahatan untuk memutus mata rantai kejahatan pencucian uang dan meruntuhkan roda bisnis dari organisasi kejahatan.

Dalam konsep "follow the money" apabila terjadi kejahatan pencucian uang maka penelusuran harta kekayaan merupakan salah satu aspek penting selain menangkap para pelaku pencucian uang. Konsep "follow the money" juga mendorong penegak hukum untuk tidak diam menunggu kejahatan terjadi kemudian bertindak melainkan selalu berkoordinasi dengan Financial Intelligence Unit (FIU) atau di Indonesia dikenal PPATK, yang mengawasi segala bentuk transaksi mencurigakan yang terjadi. Jika ditemukan aset yang mencurigakan asal usulnya maka penyidik Polri atau Penyidik Pegawai Negeri Sipil (PPNS) bisa memulai penyelidikan berdasarkan laporan dari PPATK. Penegakan hukum kasus pencucian uang di Indonesia sampai saat ini masih berorientasi pada pelaku "follow the suspect" salah satu alasan untuk mendukung argumen ini adalah dalam pandangan hukum pencucian uang Indonesia sepanjang belum adanya pemidanaan terhadap pelaku tindak pidana dalam perkara asal, maka segala hal terkait dengan aset tidak bisa dilakukan. Pendekatan "follow the money" dan "follow the suspect" tidak dapat

27 July Wiarti, 'Non-Conviction Based Asset Forfeiture Sebagai Langkah Untuk Mengembalikan Kerugian Negara (Perspektif Analisis Ekonomi Terhadap Hukum)' (2017) 1 (1) UIR Law Review 101 . 
berjalan sendiri-sendiri. Untuk memperoleh hasil yang maksimal dalam penegakan hukum yaitu memberi efek jera kepada pelaku dan memberikan detterent effect bagi publik dan merampas hasil tindak pidana untuk negara diperlukan kerja sama para penegak hukum untuk mengkombinasikan kedua pendekatan tersebut. 28

Proses pertama apabila harta kekayaan milik pelaku yang dideteksi oleh penegak hukum diduga berasal dari tindak pidana harta kekayaan akan disita terlebih dahulu untuk proses penyidikan penyidik akan melakukan penyidikan untuk menentukan jenis tindak pidana pencucian uang. Setelah diketahui harta tersebut merupakan harta kekayaan hasil tindak pidana, selanjutnya penyidik akan berkerja sama dengan PPATK untuk menelusuri secara mendalam harta kekayaan lain yang diduga berasal dari tindak pidana. (Dalam melakukan penyidikan ada kemungkinan penyidik melakukan upaya paksa penyitaan terhadap harta kekayaan yang diduga berasal dari hasil tindak pidana. Apabila penyidikan tindak pidana pencucian uang dinilai penyidik sudah selesai, maka sesuai dengan Pasal 75 KUHAP, Berita Acara Pemeriksaan (BAP) segera diserahkan kepada Jaksa Penuntut Umum). Apabila dinilai sudah cukup maka penyidik dengan laporan dari PPATK akan berkoordinasi dengan pihak penuntut umum berkaitan dengan jumlah total harta kekayaan yang berasal dari tindak pidana tersebut beserta pelimpahan berkas perkara tindak pidana pencucian uang dari tersangka.

Dalam Undang-Undang PP TPPU Pasal 77 terdakwa diwajibkan untuk membuktikan harta kekayaannya bukan merupakan hasil tindak pidana. Jika terdakwa berhasil untuk membuktikan bahwa harta kekayaannya tersebut berasal dari hasil yang sah maka keadaan ini dapat memberikan petunjuk kepada hakim dalam pengambilan keputusan. Disisi lain jaksa penuntut umum tetap harus membuktikan unsur-unsur pasal yang didakwakan. Selanjutnya alat bukti yang diajukan di persidangan baik oleh terdakwa maupun jaksa penuntut umum akan dilakukan penilaian oleh hakim. Dalam hal putusan pengadilan menyatakan harta kekayaan terdakwa bukan hasil dari tindak pidana, maka harta kekayaan tersebut tetap dalam penguasaan terdakwa ataupun ahli warisnya dan ada kemungkinan terdakwa memperoleh putusan bebas (Vrijspraak) atau putusan lepas dari segala tuntutan hukum (Ontslag van alle rechtsvervolging). Sebaliknya jika putusan Pengadilan menyatakan harta kekayaan terdakwa hasil dari tindak pidana, maka terdakwa dijatuhi pidana dan harta kekayaannya dirampas untuk negara.

Pembuktian terbalik yang terbatas dan berimbang diterapkan dalam pembuktian asal usul harta kekayaan yang dimiliki oleh terdakwa. Jaksa penuntut umum memiliki dugaan kuat (probable cause) bahwa aset yang dimiliki oleh terdakwa berasal dari tindak pidana. Dan akibat dari perbuatan yang dilakukan oleh terdakwa, kelompok atau korporasi atau negara yang dirugikan secara materiil. Oleh karena itu pidana tambahan dapat dijatuhkan bersama-sama pidana pokok penjatuhan pidana tambahan perampasan harta kekayaan milik terdakwa ditujukan sebagai bentuk tambahan hukuman yang juga memiliki tujuan utama yaitu untuk memulihkan lagi keadaan ke semula.

Dalam menjatuhkan putusan perampasan harta kekayaan hakim tetap harus memperhatikan bahwa tidak semua harta kekayaan yang dimiliki terdakwa dirampas melainkan harta kekayaan yang dapat dibuktikan oleh penuntut umum 
berasal dari tindak pidana saja. Menurut Roberts harta kekayaan yang dapat dirampas disesuaikan dengan jenis tindak pidana yang terkait dengan harta kekayaan yaitu:

1. Setiap harta kekayaan hasil tindak pidana atau yang diperoleh dari hasil tindak pidana;

2. Harta kekayaan yang digunakan sebagai alat, sarana, atau prasarana untuk melakukan tindak pidana atau mendukung organisasi kejahatan;

3. Setiap harta kekayaan yang terkait dengan tindak pidana atau organisasi kejahatan;

4. Harta kekayaan yang digunakan untuk membiayai tindak pidana atau organisasi kejahatan;

5. Segala sesuatu yang menjadi hak milik pelaku tindak pidana atau organisasi kejahatan 29 .

Jika dihubungkan dengan mekanisme pembuktian terbalik dalam perkara pencucian uang maka apabila terdakwa tidak dapat membuktikan bahwa harta kekayaan berasal dari kegiatan yang sah maka melalui putusan pengadilan yang telah berkekuatan hukum tetap Harta kekayaan yang telah disita sebelumnya akan dirampas kemudian diserahkan ke kas negara dalam bentuk Pendapatan Negara Bukan Pajak (PNBP). Jika melihat dalam putusan pengadilan maka pidana tambahan perampasan harta kekayaan hasil tindak pidana ini dijatuhkan bersamasama pidana pokok. Pidana pokok dijatuhkan sebagai hukuman atas perbuatan yang dilakukan sedangkan pidana tambahan perampasan harta kekayaan dijatuhkan berkorelasi dengan pengembalian kerugian negara atas perbuatan yang dilakukan oleh terpidana. Hal ini sejalan dengan apa yang ditentukan dalam Pasal 10 huruf b angka 2 juncto Pasal 39 Kitab Undang-Undang Hukum Pidana (KUHP). Proses selanjutnya adalah penuntut umum setelah mendapatkan salinan putusan yang telah berkekuatan hukum tetap akan segera mengeksekusi aset atau harta kekayaan milik terdakwa.

Setelah ada putusan yang berkekuatan hukum tetap (in kracht van gewijsde) maka harta kekayaan hasil tindak pidana yang telah disita sebelumnya akan dilelang. Institusi Kejaksaan Agung dan KPK berkerja sama dengan KPKNL (Kantor Pelayanan Kekayaan Negara dan Lelang) pada waktu tertentu akan melelang harta kekayaan tersebut kemudian hasil dari proses lelang tersebut diserahkan ke kas negara. Salah satu contohnya adalah KPK telah mengeksekusi aset dengan nilai total Rp 136 Miliar harta kekayaan yang berasal dari korupsi milik Muhammad Nazzaruddin, dari tidak kurang Rp 550 Miliar harta kekayaan yang telah diputus, dirampas untuk negara oleh pengadilan.

Sampai saat ini proses eksekusi perampasan harta kekayaan hasil tindak pidana tidak dapat diterapkan secara efektif dikarenakan terkendala oleh beberapa faktor yang melatarbelakangi yaitu: Pertama, lamanya proses hukum pidana di Indonesia dari tingkat pertama sampai berkekuatan hukum tetap. Kedua, kurangnya sarana dan prasarana dalam Rupbasan (Rumah Untuk Penyimpanan Benda Sitaan Negara) atau gudang barang bukti dari instansi penegak hukum terkait. Ketiga, kurangnya anggaran untuk perawatan dari harta kekayaan tersebut 
mulai dari penyitaan sampai dirampas oleh negara, tidak jarang nilai dari aset tersebut jatuh dari harapan karena sudah tidak terawat dan mengalami kerusakan. Keempat, minimnya pengawasan oleh instansi terkait sehingga tidak jarang harta kekayaan yang seharusnya dirampas dapat dimanfaatkan untuk keuntungan oknum tertentu atau dalam kasus korupsi misalnya aset hasil korupsi yang tidak dilakukan penyitaan ketika proses persidangan telah dipindahtangankan terlebih dahulu agar tidak dirampas oleh Negara. 30

Dalam praktik sebenarnya berbagai bentuk pidana tambahan seperti penjatuhan pidana denda, perampasan harta kekayaan, dan pembayaran uang pengganti (khusus UU Pemberantasan Tipikor) memiliki efek deterent yang sangat ampuh untuk memberikan efek jera baik untuk pelaku perseorangan ataupun bagi organisasi kejahatan. Selain memberikan efek jera pidana tambahan di atas juga mendorong Penerimaan Negara Bukan Pajak (PNBP) dan termasuk upaya pengembalian kerugian negara (Asset Recovery). Pengembalian kerugian negara merupakan hal penting dalam proses penegakan hukum di Indonesia, daripada pemidanaan bagi pelaku, mengingat bahwa sampai saat ini pidana penjara tidak efektif karena banyak sekali faktor yang melatarbelakangi yang membuat Lembaga Permasyarakatan (LP) bukan lagi tempat pelaksanaan hukuman melainkan tempat aman untuk melakukan tindak pidana tanpa dapat dideteksi ataupun ditindak oleh otoritas penegak hukum.

Namun permasalahan baru sebenarnya timbul setelah mencuatnya kasus penggelapan dana Umrah dan Haji First Travel yang terjadi beberapa waktu lalu yang menimbulkan kerugian sangat besar baik itu korban perorangan ataupun perusahaan rekanan para korban meminta agar harta kekayaan milik terpidana dapat disita dan dikembalikan kepada yang berhak untuk menutup kerugian yang dialami oleh para korban. Namun Majelis Hakim dalam petikan putusan memutuskan bahwa harta kekayaan yang tersisa dalam kasus First Travel dirampas untuk negara. Dalam petikan putusan Majelis Hakim berpendapat bahwa akan menimbulkan ketidakpastian hukum apabila sisa harta kekayaan tersebut dikembalikan kepada korban, sehingga untuk memenuhi rasa keadilan maka harta kekayaan tersebut dirampas untuk negara. Menurut Majelis Hakim akan sulit untuk menentukan korban yang paling berhak mendapatkan kompensasi apabila harta kekayaan dirampas dan dikembalikan kepada pihak korban.

Unsur Harta kekayaan merupakan unsur penting dalam rumusan delik pencucian uang, undang-undang telah mengakomodir pengembalian kerugian negara melalui sanksi pidana denda, perampasan harta kekayaan hasil kejahatan, atau pembayaran uang pengganti (diterapkan pada Tipikor saja). Sedangkan jika yang dirugikan perseorangan atau korporasi undang-undang tidak mengatur prosedur ataupun sanksi pengembalian harta kekayaan kepada pihak yang dirugikan. Oleh karena itu diperlukan penyempurnaan terhadap regulasi yang mengatur tentang tindak pidana pencucian uang agar jika terjadi kasus sama di kemudian hari, harta kekayaan yang berasal dari tindak pidana dapat dikembalikan kepada pihak yang dirugikan selain negara.

30 Ahmad Sanusi, 'Optimalisasi Tata Kelola Benda Sitaan Negara Pada Rumah Penyimpanan Benda Sitaan Negara' (2018) 12 (2) Jurnal Ilmiah Kebijakan Hukum 199. 
Selain penyempurnaan dalam aspek pengembalian harta kekayaan kepada pihak yang dirugikan, sudah sangat urgen bagi pembentuk Undang-Undang agar segera merubah konsep Undang-Undang pencucian uang yang berorientasi dari pelaku "follow the suspect" menjadi orientasi "follow the money". Konsep "follow the money" memberikan keleluasaan bagi penegak hukum untuk menggunakan instrumen Non-conviction based forfeiture atau perampasan aset tanpa pemidanaan. Instrumen Non-conviction based forfeiture telah dipraktikkan oleh banyak negara dan terbukti efektif dalam memberantas tindak pidana pencucian uang di berbagai belahan dunia.

Perampasan tanpa pemidanaan dalam beberapa sistem hukum disebut perampasan objektif merupakan tindakan yang ditujukan terhadap aset atau harta kekayaan bukan terhadap individu. ${ }^{31}$ Perampasan ini terpisah dan bukan bagian dari proses peradilan pidana dan mekanismenya hanya membutuhkan harta kekayaan atau aset yang diduga berasal dari tindak pidana, berdasarkan hasil penyidikan, meskipun Undang-Undang PP TPPU memiliki upaya perampasan tanpa pemidanaan dalam Pasal 67 ayat (2) yang secara eksplisit menyatakan "Dalam hal diduga pelaku tindak pidana tidak diketemukan dalam waktu 30 (tiga puluh) hari, penyidik dapat mengajukan permohonan kepada pengadilan negeri untuk memutuskan Harta kekayaan tersebut sebagai aset negara atau dikembalikan kepada yang berhak". Sayangnya instrumen Pasal ini tidak memiliki penjelasan yang komprehensif tentang upaya perampasan harta kekayaan tanpa pemidanaan tersebut. Sehingga dalam praktik instrumen perampasan tanpa pemidanaan ini jarang dilakukan oleh aparat penegak hukum di Indonesia. Sebagai perbandingan, perampasan tanpa pemidanaan terhadap pelaku juga dikenal di dalam UndangUndang Nomor 7 Tahun 1955 tentang Pengusutan, Penuntutan Dan Peradilan Tindak Pidana Ekonomi. Pada Pasal 13 disebutkan "hak melaksanakan perampasan tidak lenyap karena meninggalnya si terhukum. Lebih lanjut dijelaskan pada Pasal 16 ayat (1) bahwa, "jika ada cukup alasan untuk menduga, bahwa seseorang yang meninggal dunia, sebelum atas perkaranya ada putusan yang tak dapat diubah lagi, telah melakukan tindak pidana ekonomi, maka hakim atas tuntutan penuntut umum dengan putusan pengadilan dapat: a. memutus perampasan barang-barang yang telah disita). Maksud dari Pasal 16 ayat (1) dan Pasal 16 ayat (1) huruf (a) tersebut adalah harta yang meninggal dunia dapat dirampas oleh negara sepanjang belum ada putusan yang tidak dapat diubah lagi (inkracht).

Oleh karena itu saat ini dibutuhkan payung hukum yang tegas yang mengatur tentang akibat hukum terhadap Harta kekayaan hasil tindak pidana. Namun tidak dapat ditampik bahwa proses penegakan hukum sangat tergantung pada political will dari semua stakeholder di negara Indonesia sebagai penentu arah kebijakan hukum pidana di negara ini, diperlukan juga peran aktif dari setiap pihak untuk menekan dan mengkritisi para stakeholder tersebut. Dengan harapan agar para pemangku kepentingan tersebut sadar akan keadaan negara ini kemudian dengan segala upaya yang nyata memerangi tindak pidana pencucian uang bukan sebagai bentuk pencitraan agar dirinya kembali terpilih duduk di parlemen atau pemerintahan.

$31 \quad$ Yusuf (n 23) 105. 


\section{PENUTUP}

Pembuktian terbalik dalam Undang-Undang PP TPPU diterapkan terhadap harta kekayaan terdakwa. Jaksa Penuntut Umum tetap berkewajiban untuk membuktikan bahwa harta kekayaan terdakwa berasal dari tindak pidana, namun konsep pembuktian terbalik yang diatur dalam Pasal 77 dan Pasal 78 yang diterapkan baik untuk tindak pidana pencucian uang aktif (Pasal 3 dan Pasal 4) dan tindak pidana pencucian uang pasif (Pasal 5) tidak dijelaskan secara jelas dan tegas dalam Undang-Undang PP TPPU, sehingga menimbulkan ketidakjelasan dalam pelaksanaannya.

Akibat hukum terhadap harta kekayaan terdakwa dalam pembuktian terbalik perkara pencucian uang yaitu apabila terdakwa berhasil membuktikan bahwa harta tersebut bukan berasal dari tindak pidana maka harta kekayaan tersebut tetap dalam penguasaan terdakwa dan ahli warisnya. Namun jika terdakwa tidak mampu membuktikan bahwa harta tersebut bukan berasal dari tindak pidana maka harta kekayaan tersebut dalam putusan hakim akan dirampas untuk negara.

Dalam aspek pembuktian tindak pidana pencucian uang harus ada perubahan yang komprehensif dan tegas agar proses pembuktian terbalik (dalam pelaksanaannya lebih menjamin kepastian hukum) dan perlu segera disahkannya RUU Perampasan Aset yang saat ini sedang disusun di DPR RI agar dapat membantu instansi penegak hukum dalam upaya pemberantasan tindak pidana pencucian uang di Indonesia serta mendorong proses penegakan hukum yang lebih efektif yaitu dengan merampas aset hasil dari tindak pidana pencucian uang.

\section{DAFTAR REFERENSI}

\section{Buku}

Alfitra, Hukum Pembuktian Dalam Beracara Pidana, Perdata, dan Korupsi di Indonesia (Raih Asa Sukses Jakarta 2012).

Atmasasmita R, Sistem Peradilan Pidana Kontemporer (Kencana Prenada Media Group Jakarta 2011).

Fuady M, Bisnis Kotor: Anatomi Kejahatan Kerah Putih (PT Citra Aditya Bakti, Bandung 2011).

Hiariej EOS, Teori dan Hukum Pembuktian (Erlangga Jakarta 2012).

Kennedy R, Pengembalian Aset Hasil Kejahatan (Dalam Prespektif Rezim Anti Pencucian Uang) (Rajawali Pers Depok 2017).

Kristiana Y, Pemberantasan Tindak Pidana Pencucian Uang Prespektif Hukum Progresif (Thafamedia. Yogyakarta 2015).

Sjahdeini SR, Seluk Beluk Tindak Pidana Pencucian Uang dan Pembiayaan Terorisme (Ed. 2, Pustaka Utama Grafiti Jakarta 2007).

Sutedi A, Tindak Pidana Pencucian Uang (PT Citra Aditya Bakti, Jakarta 2008).

Wiyono, Pembahasan Undang-Undang Pencegahan dan Pemberantasan Tindak Pidana Pencucian Uang (Sinar Grafika Jakarta 2014). 
Yusuf M, Mengenal, Mencegah, Memberantas Tindak Pidana Pencucian Uang (Jakarta: Pustaka Juanda Tigalima 2014).

\section{Koran}

Yusuf M, 'Merampas Aset Koruptor Solusi Pemberantasan Korupsi di Indonesia' Kompas Jakarta, 6 April 2013) <https:/ / edukasi.kompas.com/read/2013/04/16/13412749/rampas.aset.ko ruptor.solusi.pemberantasan.korupsi. > di akses tanggal 6 Juni 2020.

\section{Artikel Jurnal}

Da Rosa S, 'Perlindungan Terhadap Pelaku Tindak Pidana Korupsi Dalam Pelaksanaan Perampasan Aset Secara Tidak Wajar' (2018) 2 (2) Jurnal Bina Mulia Hukum.

Halif, 'Penyelesaian Tindak Pidana Pencucian Uang Yang Tidak Dibuktikan Terlebih Dahulu Tindak Pidana Asalnya' (2016) 14 (2) Jurnal Era Hukum.

Muabezi Z A, 'Negara Berdasarkan Hukum (Rechtsstaats) Bukan Kekuasaan (Machtsstaat)' (2017) 6 (3) Jurnal Hukum Dan Peradilan.

Mulyadi L, 'Asas Pembalikan Beban Pembuktian Terhadap Tindak Pidana Korupsi Dalam Sistem Hukum Pidana Indonesia Dihubungkan Dengan Konvensi Perserikatan Bangsa-Bangsa Anti Korupsi 2003' (2015) 4 (1) Jurnal Hukum dan Peradilan.

Munawar KAS, 'Pembuktian Terbalik Sebagai Kebijakan Kriminal Dalam Penanganan Tindak Pidana Korupsi ‘ (2017) 5 (2) Jurnal Ilmiah Galuh Justisi.

Sagita A, 'Pembaharuan Kebijakan Hukum Pidana Terkait Beban Pembuktian Pada Tindak Pidana Korupsi Dalam Rangka Pengembalian Kerugian Keuangan Negara' (2018) 17 (2) Jurnal Hukum Respublica.

Sagita A, 'Pembalikan Beban Pembuktian Sebagai Kebijakan Hukum Pidana Dalam Undang-Undang Tindak Pidana Korupsi. Jurnal Hukum Respublica (2017) 17 (1) Jurnal Hukum Respublica.

Sanusi A, 'Optimalisasi Tata Kelola Benda Sitaan Negara Pada Rumah Penyimpanan Benda Sitaan Negara' (2018) 12 (2) Jurnal Ilmiah Kebijakan Hukum.

Sinaga LV, 'Alvi Syahrin, M. Hamdan, Dedi Harianto, Penerapan Pembuktian Terbalik Dalam Perkara Gratifikasi' (2016) 4 (2) USU Law Journal.

Tanjung N, 'Pembuktian Terbalik Atas Harta Kekayaan Seseorang Tersangka Korupsi' (2016) 5 (2) Lex Crimen.

Wiarti J, 'Non-Conviction Based Asset Forfeiture Sebagai Langkah Untuk Mengembalikan Kerugian Negara (Perspektif Analisis Ekonomi Terhadap Hukum)' (2017) 1 (1) UIR Law Review.

\section{Peraturan Perundang-Undangan}

Kitab Undang-Undang Hukum Pidana. 
Undang-Undang Nomor 7 Tahun 1955 tentang Pengusutan, Penuntutan Dan Peradilan Tindak Pidana Ekonomi.

Undang-Undang Nomor 39 Tahun 1999 tentang Hak Asasi Manusia.

Undang-Undang Nomor 31 Tahun 1999 tentang Pemberantasan Tindak Pidana Korupsi sebagaimana telah diubah dengan Undang-Undang Nomor 20 Tahun 2001 tentang Perubahan atas Undang-Undang Nomor 31 Tahun 1999 tentang Pemberantasan Tindak Pidana Korupsi.

Undang-Undang Nomor 48 Tahun 2009 tentang Kekuasaan Kehakiman.

Undang-Undang Nomor 8 Tahun 2010 tentang Pencegahan Dan Pemberantasan Tindak Pidana Pencucian (Lembaran Negara Republik Indonesia Tahun 2010 Nomor 122, Tambahan Lembaran Negara Nomor 5164). 
